\title{
Mapping of Shifting Cultivation (Gilir Balik) Patterns in Dayak Meratus Tribe
}

\author{
Muhammad Muhaimin ${ }^{1 *}$ Aswin Nur Saputra ${ }^{1}$ Parida Angriani ${ }^{1}$ Sidharta Adyatma ${ }^{1}$ \\ Deasy Arisanty ${ }^{1}$
}

\author{
${ }^{1}$ Geography Education Department, Faculty of Teacher Training and Education, Lambung Mangkurat University, \\ Banjarmasin, Indonesia \\ *Corresponding author.Email: muhammad.muhaimin@ulm.ac.id
}

\begin{abstract}
Shifting cultivation is the dominant land-use system in the Loksado Subdistrict. The shifting cultivation products provide various valuable subsistence products for Meratus Dayak farmers. The shift farming system is controversial because it is closely related to environmental problems. Shifting cultivation has undergone a drastic change to market-oriented land use. However, there is limited information on geographic data in the form of the spatial distribution of shifting fields. This is very important for the monitoring and evaluation of shifting agriculture. Remote sensing techniques provide an effective way to detect, monitor the location and extent of shifting cultivation. The method used is through visual interpretation of Sentinel 2 satellite images. The total increase in the number of shifting fields is 159 fields or $11.5 \%$ and the area of shifting cultivation has increased by 219.5 hectares or $8.17 \%$ in 2019 .
\end{abstract}

bags.

Keywords: shifting cultivation, remote sensing, dayak meratus tribe

\section{INTRODUCTION}

Shifting cultivation is a very primitive farming system carried out in shifts from one place to another in rotation, which is usually carried out by indigenous peoples on dryland farming systems in the tropics. The shifting cultivation is based on the community's experience from generation to generation in cultivating the land. The shifting cultivation system originated in the Neolithic period around 7000 BC. The shifting cultivation system is generally carried out by traditional communities in an area with a low population density [1-5].

Shifting cultivation refers to an agricultural system where the cultivation phase is short but varies in slash and burn land which alternates with long and equal fallow periods. The shifting cultivation system can be found in Asian, African, South American, and Australian countries which is mostly practiced by tribes in tropical and subtropical regions. Crops such as rice, corn, cassava, sweet potatoes, taro, bananas, and candlenut [3],[5],[6]. In Indonesia, the shifting cultivation system has long been carried out in several regions outside Java, including on the islands of Sumatra, Kalimantan, Sulawesi, Maluku, and Irian. While there is a limited number of islands in Java, which is only found in a few regions of South Sukabumi [7].

One area of South Kalimantan that still uses a shifting cultivation system is in Loksado Sub-District, Hulu Sungai Selatan Regency, which is carried out by the Meratus Dayak community. Their shifting cultivation system is named the turn-back cultivation system which has a more positive connotation [8]. The Dayaks are thought to have been doing shifting cultivation since two centuries ago [9], although farming methods in the Kalimantan region have been known to occur since 6000 years BC [10].

The Dayak community has a knowledge system about the management of forest and garden resources by making a classification of forest arrangements based on their use and protection for life. The Dayak community carried out farming activities using only their production areas such as the former agricultural land a few years earlier or the former unproductive plantation land, so the Meratus Dayak community carried out shifting cultivation activities but rotated their lands in a 5-13 years cycle [6],[8],[11],[12]. So the research objective is to map the distribution patterns of the Gilir Balik field of Meratus Dayak community from 2017 to 2019.

\section{THEORETICAL FRAMEWORK 2.1 Shifting Cultivation (Gilir Balik)}

The system of shifting cultivation or slash-and-burn agriculture is a long-standing practice of subsistence farming and applies in the tropics [13-16]. Shifting cultivation is an important form of agriculture for livelihoods, nutritional needs, and support for millions of people in the tropics [17],[18]. Moving fields can contribute to biodiversity conservation, soil and water conservation, and climate change mitigation [19-21] but, simultaneously shifting cultivation systems have been widely criticized by researchers and policymakers for being considered damaging to the environment and referred to as empty land in government archives [22-24]. There are 40 to 50 countries globally implementing shifting cultivation systems [25] with almost 300-500 million people directly or 
indirectly operating this traditional system in almost half of the land area in the tropics [26-29].

The Meratus Dayak traditional village in Loksado SubDistrict, Hulu Sungai Selatan Regency, which is included in the South Hulu Sungai Protected Forest Management Unit (KPHL), is still found with local wisdom in terms of land management, one of which is a shifting cultivation system. The shifting cultivation system is a farmer's activity in a location for one season, then leaving the land for a minimum of 7 years. As long as the land is abandoned, or what is commonly referred to as the "Bera" period, farmers will farm elsewhere. Land for farming used by farmers in Loksado is usually their ancestral heritage. Rotational farms generally have 7 to 10 locations of farmland [12],[30].

The Meratus Dayak community conducts "Behuma" (farming) activities through regular and planned stages. Each stage is carried out through religious rituals for ease and success in their behavioral activities, which consist of "Batanung, Batabas / Manabas, Batabang, Manyalukut, Mamanduk, Menugal / bemata umang, mamanduk, Marumput, Aruh Basambu, Manyambut, Maampatungi banih / maambil banih, and Mangatam / harvest are stages in shifting cultivation" [6],[12],[30]. Gratitude for behuma activities carried out in an aruh event. The Aruh Ganal party, also called Bawanang Banih Halin or Mahanyari Banih Barat ceremony, is held once a year in Balai Adat, conducted after the harvest around July and August. The length of Aruh Ganal is varied, between five to twelve days depending on how much the community harvests [6],[30].

\subsection{Remote Sensing for Shifting Cultivation Mapping}

Geographic research on shifting cultivation was initially descriptive because of the constraints of monitoring techniques and data at the macroscopic scale [31]. Thematic map data and statistical data on shifting cultivation on a regional or national scale are still relatively lacking [32], this greatly limits understanding of the environmental and livelihood consequences of local populations due to the rapid changes in shifting cultivation.

In the 1970s the development of remote sensing technology, is the most appropriate tool for monitoring environmental degradation and has resulted in the development of an accurate methodology for mapping and monitoring various degraded lands one of which is shifting cultivation [33]. Diverse, complex, and dynamic shifting cultivation makes an approach with remote sensing imagery much needed [24],[32],[34].
Various sources of satellite imagery have been provided to monitor biophysical changes on the surface of the earth including optical and radar remote sensing data. Satellite data that can be used to describe shifting fields are medium spatial resolution images represented by Landsat and Sentinel 2 images, while low spatial resolution images are represented by MODIS and Synthetic Aperture Radar (SAR) data [35-38].

\section{METHOD}

\subsection{Study Area Description}

The research area is located in Loksado District, Hulu Sungai Selatan Regency, South Kalimantan Province. The boundary of the North Loksado Subdistrict is bordered by the Hulu Sungai Tengah Regency, the southern part borders the Banjar and Tapin Regencies, the West borders the Padang Batung District, and the East borders the Kotabaru Regency and the Tanah Bumbu Regency. Loksado District is in the Meratus Mountains region which is located between $115^{\circ} 38^{\prime} 00$ "to $115^{\circ} 52^{\prime} 00^{\prime \prime}$ East Longitude and $2^{\circ} 28^{\prime} 00$ "to $20^{\circ} 54^{\prime} 00^{\prime \prime}$ South Latitude. The map of Loksado Subdistrict is presented in Figure 1.

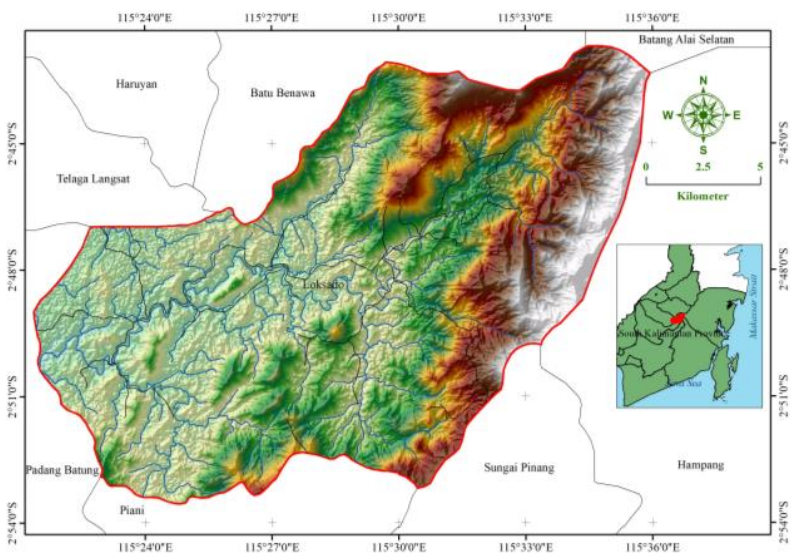

Figure 1 Map of Loksado Subdistrict

\subsection{Sentinel 2A Image Selection and Pre- Processing}

The image used in this study is MSI Sentinel-2. MSI Sentinel-2 is an imagery system filter-based push-broom. The recording uses 13 spectral bands spread across the VNIR and SWIR domains with spatial resolutions ranging from 10 to $60 \mathrm{~m}$. Spectral channels MSI Sentinel-2are shown in Table 1.

Table 1 Spectral Channels MSI Sentinel-2

\begin{tabular}{|c|c|c|c|}
\hline No & Sentinel 2 Bands & Central Wavelength $(\boldsymbol{\mu m})$ & Resolution $(\mathbf{m})$ \\
\hline 1 & Band 1 - Coastal Aerosol & 0.443 & 60 \\
\hline 2 & Band 2 - Blue & 0.490 & 10 \\
\hline 3 & Band 3 - Green & 0.560 & 10 \\
\hline 4 & Band 4 - Red & 0.665 & 10 \\
\hline 5 & Band 5 - Red Edge Vegetation & 0.705 & 20 \\
\hline 6 & Band 6 - Red Edge Vegetation & 0.740 & 20 \\
\hline
\end{tabular}




\begin{tabular}{|c|c|c|c|}
\hline 7 & Band 7 - Red Edge Vegetation & 0.783 & 20 \\
\hline 8 & Band 8 - NIR & 0.842 & 10 \\
\hline 9 & Band 8A - Vegetation Red Edge & 0865 & 20 \\
\hline 10 & Band 9 - Water Vapor & 0945 & 60 \\
\hline 11 & Band 10 - SWIR-Cirrus & 1375 & 60 \\
\hline 12 & Band 11 - SWIR & 1610 & 20 \\
\hline 13 & Band 12 - SWIR & 2,190 & 20 \\
\hline
\end{tabular}

Sentinel 2 imagery is used for the identification of shifting cultivation was recorded in October 2017, October 2018, and September 2019 with the selection of spectral channels including band 2 (Blue), band 3 (Green), band 4 (Red), and band 8 (NIR). This channel selection aims to display the composite true color and standard false color for the process of visual interpretation. The Sentinel 2 image that has been selected is geometric correction and atmospheric correction is not done because the study area is cloud-free and the process of identifying shifting cultivation areas uses visual interpretation. Visual interpretation is done by digitizing the appearance that is estimated as a field so that a tentative map or presumption is obtained that will be validated in the field.

\subsection{Image Classification}

Land cover classification in the form of fields is done by visual interpretation based on the identification of objects spatially using interpretation elements, namely color/hue, shape, size, pattern, shadow, texture, site, and association [39]. Obtaining the characteristics of objects in visual interpretation, the image is displayed in the format of truecolor composite and standard false color from a combination of 4 bands (blue, green, red, and NIR). The determination of the band combination is based on the Optimum Index Factor (OIF) value, which is a value that states quantitatively the variation of information on the composite color, which is the value of the comparison between the standard deviation and the correlation coefficient of the band combination used. The combination of bands in a 4 band composite with the highest OIF value is used in visual image interpretation. The classification of shifting fields visually is done by delineating each shifting field on a computer screen using ArcGis 10.5 software on a scale of 1: 25,000. Detection of shifting cultivation is done by delineating the outer boundaries of groups of the same color and separating them from the others.

\subsection{Accuracy Assessment}

The field survey was carried out to identify and determine the area of sample shifting fields for classification and testing of the accuracy of classification results using GPS and Field Area Measures. The accuracy testing of the classification of shifting and non-shifting fields is carried out to determine the accuracy of the classification results using a confusion matrix that compares the classification results with the actual data from the field checking results. Classification accuracy values are based on the producer's accuracy, user's accuracy, overall accuracy, and Kappa values [40].

\section{RESULTS AND DISCUSSION}

We present the results in three stages: map of shifting fields (in 2017, 2018 and 2019), estimates of mapping accuracy, pattern, and density of shifting fields.

\subsection{Mapping of shifting fields in Loksado Subdistrict in 2017, 2018 and 2019}

Maps of shifting fields in Loksado Subdistrict in the periods of 2017, 2018, and 2019 are presented in Figures 2, 3, and 4. There are two important results of the mapping. First, shifting cultivation (Gilir Balik) as a result of mapping and field checking is everywhere and is found throughout the Loksado District area. Second, the map shows that the area of primary forest in which there is no shifting field is located in the eastern part of the Meratus Mountains which has a steep topography and has no road access. The shifting fields of the Meratus Dayak are dominated by banana, sweet potato, cassava, papaya, peanuts, and upland rice [41].

The number of shifting fields of Meratus Dayak in Loksado District from 2017, 2018, and 2019 increased by 159 fields or $11.5 \%$ in 2019, while in 2017 and 2018 the number of shifting cultivation areas was the same or no change. The area of Meratus Dayak shifting cultivation in Loksado District from 2017, 2018, and 2019 has increased by 219.5 hectares or $8.17 \%$ in 2019 of the total area of Loksado District 32346.3 hectares, while in 2017 and 2018 the area of shifting cultivation has the same or no change. This increase in the number and extent of shifting cultivation is due to food and economic needs, with rotational farm farmers having an average of 7-10 swidden fields [8]. The number and area of districts from 2017 - 2019 are presented in Table 2 .

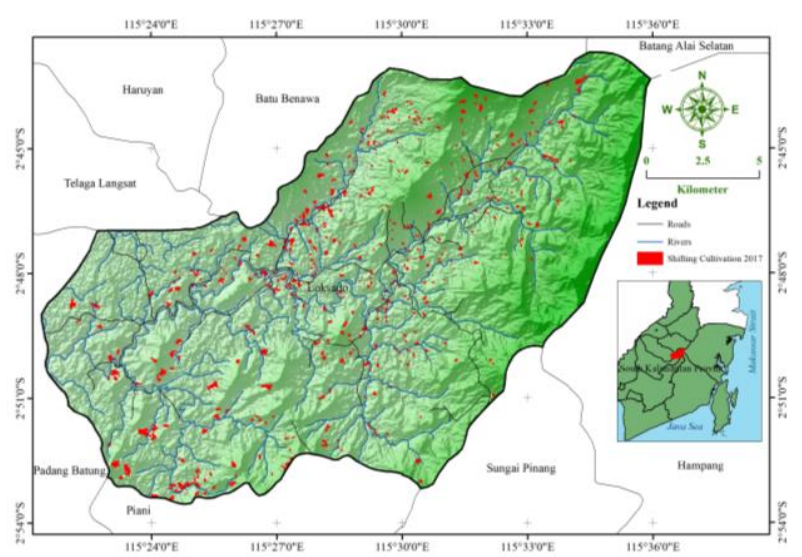

Figure 2 Shifting cultivation in Loksado District in 2017 


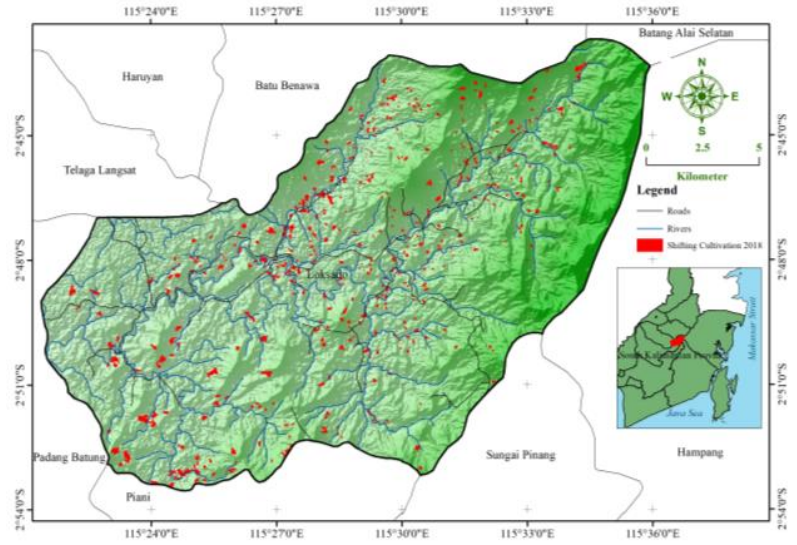

Figure 3 Shifting cultivation in Loksado District in 2018

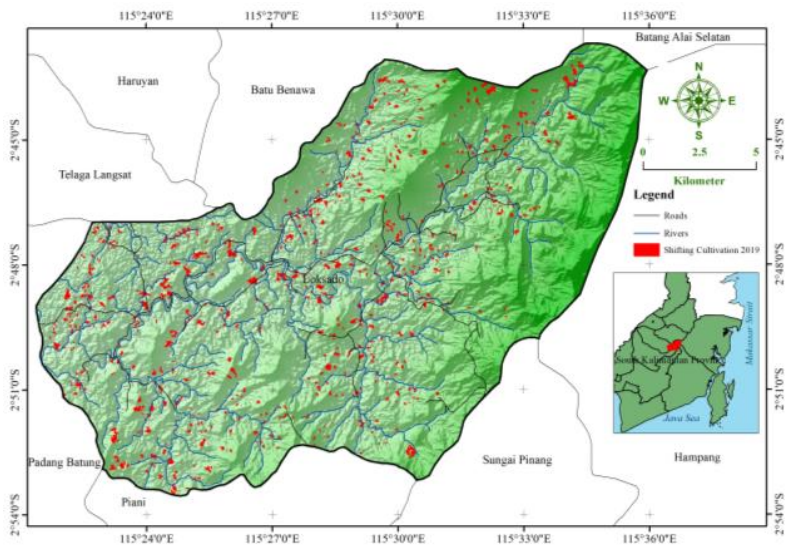

Figure 4 Shifting cultivation in Loksado District in 2019

Table 2 Total and Area of Shifting Cultivation (Gilir Balik) in Loksado District from 2017 - 2019

\begin{tabular}{|c|c|c|c|c|}
\hline \multirow[t]{2}{*}{ No } & \multirow[t]{2}{*}{ Information } & \multicolumn{3}{|c|}{$\begin{array}{c}\text { Shifting Cultivation } \\
\text { (Gilir Balik) }\end{array}$} \\
\hline & & 2017 & 2018 & 2019 \\
\hline 1 & $\begin{array}{l}\text { Total of shifting cultivation/Gilir Balik } \\
\text { (fields) }\end{array}$ & 408 & 408 & 567 \\
\hline 2 & Area of shifting cultivation $(\mathrm{Ha})$ & 822.3 & 822.3 & 1041.8 \\
\hline
\end{tabular}

\subsection{Estimation of Mapping Accuracy Mapping}

Mapping of shifting fields in Loksado District in 2017 resulted in an overall accuracy of $87,692 \%$ and a kappa index of 0708, Mapping of shifting fields in Loksado District in 2018 resulted in an overall accuracy of $89,231 \%$ and a kappa index of 0.739 , and Mapping of shifting fields in Loksado District in 2019 produced an overall accuracy of $98,462 \%$ and a kappa index of 0,958 . The resulting accuracy is very high and quite reasonable because it only maps two variables namely shifting fields with non-shifting fields. Calculation of accuracy of the mapping of shifting fields in Loksado District from 2017, 2018, and 2019 are presented in Tables 3, 4, and 5.

Table 3 Accuracy of Shifting Cultivation Mapping in Loksado District in 2017

\begin{tabular}{|c|c|c|c|c|c|}
\hline \multirow{8}{*}{ 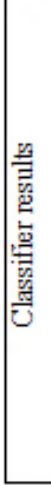 } & \multicolumn{5}{|c|}{ Truth data } \\
\hline & & $\begin{array}{l}\text { Shifting Cultivation } \\
\text { (Giliz Balik) }\end{array}$ & $\begin{array}{c}\text { Non- Shifting Cultivation } \\
\text { (Giliz Balib) }\end{array}$ & $\begin{array}{l}\text { Classification } \\
\text { overall }\end{array}$ & $\begin{array}{l}\text { Producer } \\
\text { Accuracy } \\
\text { (Precision) }\end{array}$ \\
\hline & $\begin{array}{l}\text { Shifting Cultivation } \\
\text { (Giliz Balik) }\end{array}$ & 84 & 16 & 100 & $86 \%$ \\
\hline & $\begin{array}{c}\text { Non- Shifting Cultivation } \\
\text { (Giliz Balik) }\end{array}$ & 0 & 30 & 30 & $100 \%$ \\
\hline & $\begin{array}{c}\text { Truth } \\
\text { overall }\end{array}$ & 84 & 46 & 130 & \\
\hline & $\begin{array}{c}\text { User } \\
\text { Accuracy } \\
\text { (Recall) }\end{array}$ & $100 \%$ & $65.217 \%$ & & \\
\hline & Overall accuracy $(\mathrm{OA})$ : & \multicolumn{4}{|c|}{$87692 \%$} \\
\hline & Kappa & \multicolumn{4}{|c|}{0.708} \\
\hline
\end{tabular}


Table 4 Accuracy of Shifting Cultivation Mapping in Loksado District in 2018

\begin{tabular}{|c|c|c|c|c|c|}
\hline & \multicolumn{5}{|c|}{ Truth Data } \\
\hline & & $\begin{array}{l}\text { Shifting Cultivation } \\
\text { (Giliz Balik) }\end{array}$ & $\begin{array}{l}\text { Non- Shifting Cultivation } \\
\text { (Gilir Balib) }\end{array}$ & $\begin{array}{l}\text { Classification } \\
\text { overall }\end{array}$ & $\begin{array}{l}\text { Producer } \\
\text { Accuracy } \\
\text { (Precision) }\end{array}$ \\
\hline \multirow{6}{*}{ 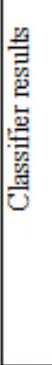 } & $\begin{array}{l}\text { Shifting Cultivation } \\
\text { (Giliz Balik) }\end{array}$ & 86 & 14 & 100 & $86 \%$ \\
\hline & $\begin{array}{l}\text { Non- Shifting Cultivation } \\
\text { (Giliz Balik) }\end{array}$ & 0 & 30 & 30 & $100 \%$ \\
\hline & $\begin{array}{c}\text { Truth } \\
\text { overall }\end{array}$ & 86 & 44 & 130 & \\
\hline & $\begin{array}{c}\text { User } \\
\text { Accuracy } \\
\text { (Recall) }\end{array}$ & $100 \%$ & $68.182 \%$ & & \\
\hline & Overall accuracy (OA): & \multicolumn{4}{|c|}{$89.231 \%$} \\
\hline & Kappa & \multicolumn{4}{|c|}{0.739} \\
\hline
\end{tabular}

Table 5 Accuracy of Shifting Cultivation Mapping in Loksado District in 2019

\begin{tabular}{|c|c|c|c|c|c|}
\hline \multirow{8}{*}{ 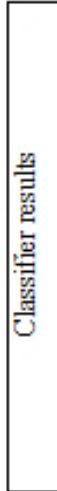 } & \multicolumn{5}{|c|}{ Truth Data } \\
\hline & & $\begin{array}{l}\text { Shifting Cultivation } \\
\text { (Giliz Balik) }\end{array}$ & $\begin{array}{c}\text { Non- Shifting Cultivation } \\
\text { (Giliz Balik) }\end{array}$ & $\begin{array}{l}\text { Classification } \\
\text { overall }\end{array}$ & $\begin{array}{l}\text { Producer } \\
\text { Accuracy } \\
\text { (Precision) }\end{array}$ \\
\hline & $\begin{array}{l}\text { Shifting Cultivation } \\
\text { (Gilin Balik) }\end{array}$ & 98 & & 2100 & $98 \%$ \\
\hline & $\begin{array}{c}\text { Non- Shifting Cultivation } \\
\text { (Giliz Balik) }\end{array}$ & 0 & 30 & 30 & $100 \%$ \\
\hline & $\begin{array}{c}\text { Truth } \\
\text { overall }\end{array}$ & 98 & 32 & 130 & \\
\hline & $\begin{array}{l}\text { User } \\
\text { Accuracy } \\
\text { (Recall) }\end{array}$ & $100 \%$ & $93.75 \%$ & & \\
\hline & Overall accuracy (OA): & & $98.462 \%$ & & \\
\hline & Kappa & & 0.958 & & \\
\hline
\end{tabular}

\subsection{Patterns and Density of Moving Fields}

Patterns of Meratus Dayak shifting cultivation in Loksado District spread in the entire sub-district area, only the eastern part of the Meratus Mountains has no fields because there is no access road and steep terrain. The highest number of shifting fields is close to the road. This supports the accessibility of cultivation and the process of transporting crops. The Meratus Dayak migratory field is also adjacent to the river flow, based on field observations the river flow is used as access to water needs by farmers. The density of shifting fields is analyzed using a kernel density to calculate the area of magnitude per unit from the point of shifting area using the kernel function. The density of shifting cultivation in Loksado Subdistrict in 2017, 2018, and 2019 are presented in Figures 5, 6, and 7. The map of shifting land density is shown in the range of green to red, the green color shows the density of low shifting fields and the red color shows the density of shifting fields high. In 2017 and 2018 it has the same spatial distribution of shifting fields centered in the middle of Loksado District which has the characteristics of the valley topography and has access to roads and rivers. In 2019 there was a change in the spatial pattern of shifting land density, the densest location of shifting land was in the West and Central part of Loksado District, but it still had the same characteristics, namely low topography, and road access and proximity to rivers.

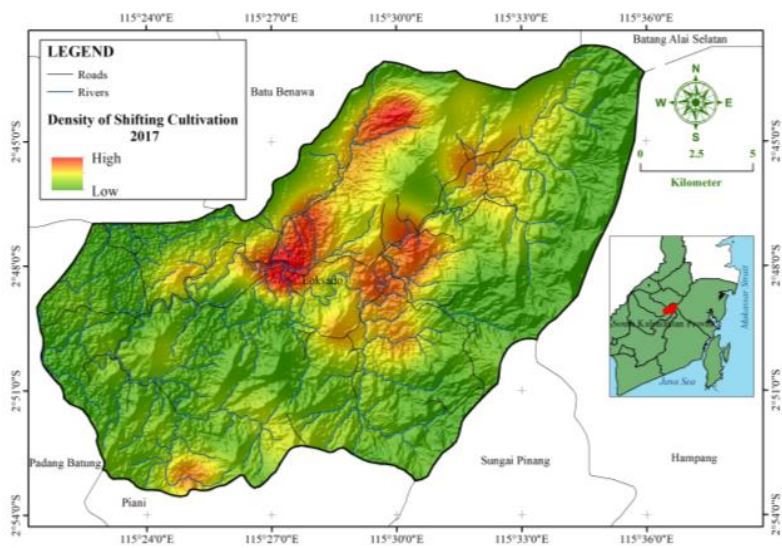

Figure 5 The density of shifting cultivation in Loksado District in 2017 


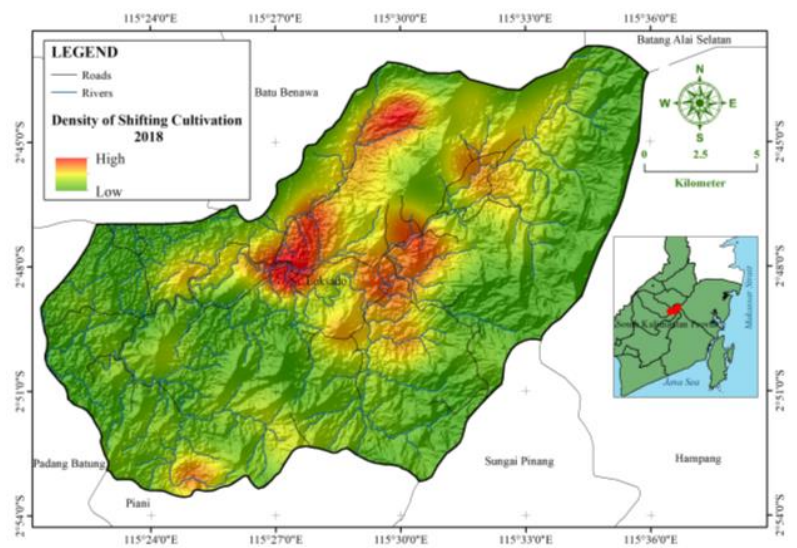

Figure 6 The density of shifting cultivation in Loksado District in 2018

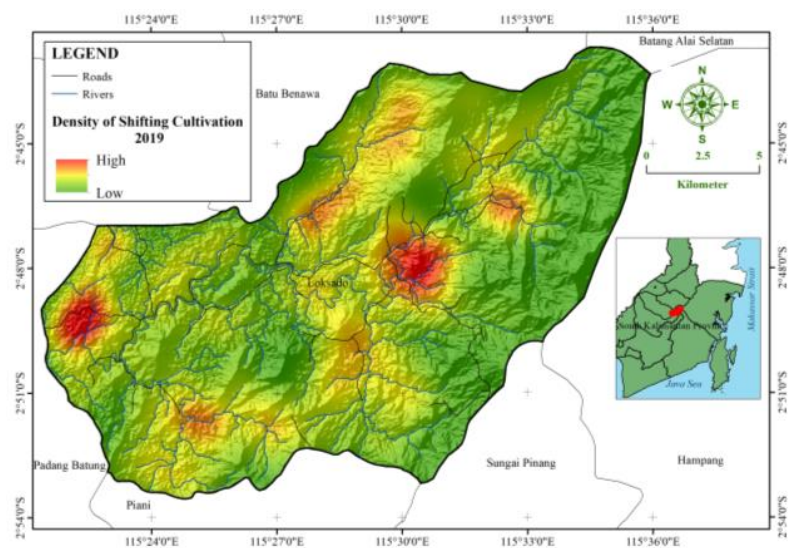

Figure 7 The density of shifting cultivation in Loksado District in 2019

\section{CONCLUSION}

This study presents the characteristics of spatial patterns and shifting cultivation in the Meratus Mountains area, Loksado District, Hulu Sungai Selatan District. The pattern of shifting cultivation that spreads throughout the Loksado District area resulted in forest fragmentation and the expansion of shifting fields resulted in changes in forest stratification. The number of shifting land of the Meratus Dayak tribe has increased by 159 fields or $11.5 \%$ in 2019 . Meanwhile, the area of shifting cultivation has increased by 219.5 hectares or $8.17 \%$ in 2019 from the total area of Loksado District 32346.3 hectares. Monitoring changes in spatial patterns and the extent of shifting land area is needed within a period of 5 to 13 years according to fallow, as an effort to monitor the balance between nature and human livelihood, because the Meratus Mountains region is made as a National Geopark area and proposed to be a UNESCO Global Geopark Meratus (UGG).

\section{ACKNOWLEDGMENT}

Thank you to the Faculty of Teacher Training and Education for supporting me to join the international conference. Thank you to my colleagues in the Department of Geography Education for being a good colleague.

\section{REFERENCES}

[1] A. Angelsen, "Shifting cultivation and 'deforestation': A study from Indonesia," World Development, vol. 23, no. 10, pp. 1713-1729, Oct. 1995, doi: 10.1016/0305-750X(95)00070-S.

[2] D. N. Borthakur, Agriculture of the North Eastern Region, with special reference to hill agriculture. Prakashan, Gauhati: BEE CEE, 1992.

[3] D. Raj, "Shifting cultivation and its merit and demerit: An overview," Aug. 01, 2014, doi: 10.13140/RG.2.1.2741.5125.

[4] M. Rifqi, "Ladang Berpindah dan Model Pengembangan Pangan Indonesia," Feb. 2017.

[5] U. Yuminarti, D. Darwanto, J. Jamhari, and S. Subejo, "Studi Komparasi Praktik Perladangan Berpindah Dan Pertanian Menetap Untuk Mendukung Ketahanan Pangan Masyarakat (Studi Pada Usahatani Kentang di Kabupaten Pegunungan Arfak)," Jurnal Ketahanan Nasional, vol. 24, p. 215, Aug. 2018, doi: $10.22146 / \mathrm{jkn} .35367$.

[6] A. Syahruji, "Masyarakat Adat Dayak Kiyu Meratus, Kalimantan Selatan,” p. 16, 2003.

[7] K. A. ; D. F. Monk, Ekologi Nusa Tenggara dan Maluku. Prenhallindo, 2000.

[8] A. Yuliono, Hamdani, and A. Y. Kurniawan, "Sistem Usahatani Perladangan Gilir Balik pada Masyarakat Dayak Meratus di Desa Haratai, Kecamatan Loksado, Kabupaten Hulu Sungai Selatan," Jurnal Agribisnis Perdesaan, vol. 01, pp. 191-2015, 2011.

[9] B. Sellato, Innermost Borneo: Studies in Dayak Cultures. NUS Press, 2002.

[10] N. Mering, "Inilah Peladang, dalam: Prospek No 3 Tahun 1," 1990, Accessed: May 04, 2020. [Online]. Available: http://arkandien.blogspot.com/2009/03/sistemperladangan-dan-kearifan.html.

[11] Balai Penelitian dan Pengembangan Lingkungan Hidup dan Kehutanan Banjarbaru, "Peladangan Gilir Balik, Salah Satu Bentuk Kearifan Lokal Masyarakat Loksado,” 2016.

[12] A. A. Rezekiah, "Sistem perladangan masyarakat Dayak Bukit Meratus di Kecamatan Loksado Hulu Sungai Selatan Kalimantan Selatan," Universitas Gadjah Mada, 2006.

[13] N. C. Brady, "Alternatives to slash-and-burn: a global imperative," Agriculture, Ecosystems \& Environment, vol. 58, no. 1, pp. 3-11, Jun. 1996, doi: 10.1016/0167-8809(96)00650-0.

[14] I. Comte et al., "Physicochemical properties of soils in the Brazilian Amazon following fire-free land preparation and slash-and-burn practices," Agriculture, Ecosystems \& Environment, vol. 156, pp. 108-115, Aug. 2012, doi: 10.1016/j.agee.2012.05.004. 
[15] Y. Inoue et al., "Assessing land-use and carbon stock in slash-and-burn ecosystems in tropical mountain of Laos based on time-series satellite images," International Journal of Applied Earth Observation and Geoinformation, vol. 12, no. 4, pp. 287-297, Aug. 2010, doi: 10.1016/j.jag.2010.04.004.

[16] E. C. Schuck, W. Nganje, and D. Yantio, "The role of land tenure and extension education in the adoption of slash and burn agriculture," Ecological Economics, vol. 43, no. 1, pp. 61-70, Nov. 2002, doi: 10.1016/S0921-8009(02)001805.

[17] R. A. Cramb et al., "Swidden Transformations and Rural Livelihoods in Southeast Asia," Hum Ecol, vol. 37, no. 3, pp. 323-346, Jun. 2009, doi: 10.1007/s10745-009-9241-6.

[18] N. van Vliet et al., "Trends, drivers and impacts of changes in swidden cultivation in tropical forestagriculture frontiers: A global assessment," Global Environmental Change, vol. 22, no. 2, pp. 418-429, May 2012, doi: 10.1016/j.gloenvcha.2011.10.009.

[19] T. B. Bruun, A. de Neergaard, D. Lawrence, and A. D. Ziegler, "Environmental Consequences of the Demise in Swidden Cultivation in Southeast Asia: Carbon Storage and Soil Quality," Hum Ecol, vol. 37, no. 3, pp. 375-388, Jun. 2009, doi: 10.1007/s10745-009-9257-y.

[20] J. Fox, J.-C. Castella, and A. D. Ziegler, "Swidden, Rubber and Carbon: Can REDD+ work for people and the environment in Montane Mainland Southeast Asia?," CGIAR Research Program on Climate Change, Agriculture and Food Security (CCAFS), no. CCAFS Working Paper no. 9., 2011, Accessed: May 07, 2020. [Online]. Available: https://www.eastwestcenter.org/sites/default/file s/filemanager/Research_Program/Fox_swidden_ rubber_carbon2011.pdf.

[21] A. D. Ziegler, T. B. Bruun, M. GuardiolaClaramonte, T. W. Giambelluca, D. Lawrence, and N. Thanh Lam, "Environmental Consequences of the Demise in Swidden Cultivation in Montane Mainland Southeast Asia: Hydrology and Geomorphology," Hum Ecol, vol. 37, no. 3, pp. 361-373, Jun. 2009, doi: 10.1007/s10745-009-9258-x.

[22] FAO, "Shifting cultivation." Unasylva, 1957, Accessed: May 07, 2020. [Online]. Available: http://www.fao.org/3/x5386e/x5386e07.htm.

[23] N. Myers, "Tropical forests: The policy challenge," Environmentalist, vol. 12, no. 1, pp. 15-27, Mar. 1992, doi: 10.1007/BF01267592.

[24] D. Schmidt-Vogt et al., "An Assessment of Trends in the Extent of Swidden in Southeast Asia," Hum
Ecol, vol. 37, no. 3, p. 269, May 2009, doi: 10.1007/s10745-009-9239-0.

[25] O. Mertz, "Trends in shifting cultivation and the REDD mechanism," Current Opinion in Environmental Sustainability, vol. 1, no. 2, pp. 156-160, Dec. 2009, doi: 10.1016/j.cosust.2009.10.002.

[26] J. G. Goldammer, "Rural land-use and wildland fires in the tropics," Agroforest Syst, vol. 6, no. 1, pp. 235-252, Feb. 1988, doi: 10.1007/BF02344761.

[27] E. H. Hartmans, Land development and management in tropical Africa. 1981.

[28] P. J. A. Kleinman, R. B. Bryant, and D. Pimentel, "Assessing Ecological Sustainability of Slashand-Burn Agriculture through Soil Fertility Indicators," Agronomy Journal, vol. 88, no. 2, pp 122-127, 1996, doi: 10.2134/agronj1996.00021962008800020002x.

[29] FAO, UNESCO, and UNEP, Tropical grazing land ecosystems. 1979.

[30] Balai Litbang Lingkungan Hidup dan Kehutanan, "Perladangan Gilir Balik, Kearifan Lokal Masyarakat Dayak Loksado dalam Pengelolaan Lahan," $2016 . \quad$ https://www.fordamof.org/index.php/berita/post/2829 (accessed May 08, 2020).

[31] M. Inoue, "Mechanism of Changes in the Kenyah's Swidden System:Explanation in Terms of Agricultural Intensification Theory," in Rainforest Ecosystems of East Kalimantan: El Niño, Drought, Fire and Human Impacts, E. Guhardja, M. Fatawi, M. Sutisna, T. Mori, and S. Ohta, Eds. Tokyo: Springer Japan, 2000, pp. 167184.

[32] K. Hurni, C. Hett, A. Heinimann, P. Messerli, and U. Wiesmann, "Dynamics of Shifting Cultivation Landscapes in Northern Lao PDR Between 2000 and 2009 Based on an Analysis of MODIS Time Series and Landsat Images," Hum Ecol, vol. 41, no. 1, pp. 21-36, Feb. 2013, doi: 10.1007/s10745012-9551-y.

[33] L. Venkataratnam and T. R. Sankar, "Remote sensing and GIS for assessment, monitoring and management of degraded lands," p. 14, 1996.

[34] C. Padoch, K. Coffey, O. Mertz, S. J. Leisz, J. Fox, and R. L. Wadley, "The Demise of Swidden in Southeast Asia? Local Realities and Regional Ambiguities," Geografisk Tidsskrift-Danish Journal of Geography, vol. 107, no. 1, pp. 29-41, Jan. 2007, doi: 10.1080/00167223.2007.10801373.

[35] G. A. Abubakar et al., "Mapping Maize Fields by Using Multi-Temporal Sentinel-1A and Sentinel2A Images in Makarfi, Northern Nigeria, Africa," Sustainability, vol. 12, no. 6, p. 2539, Jan. 2020 , doi: 10.3390/su12062539. 
[36] A. W. Degife, F. Zabel, and W. Mauser, "Assessing land use and land cover changes and agricultural farmland expansions in Gambella Region, Ethiopia, using Landsat 5 and Sentinel $2 \mathrm{a}$ multispectral data," Heliyon, vol. 4, no. 11, p. e00919, Nov. 2018, doi: 10.1016/j.heliyon.2018.e00919.

[37] P. Li, Z. Feng, L. Jiang, C. Liao, and J. Zhang, "A Review of Swidden Agriculture in Southeast Asia," Remote Sensing, vol. 6, no. 2, pp. 16541683, Feb. 2014, doi: 10.3390/rs6021654.

[38] J. Miettinen, H.-J. Stibig, and F. Achard, "Remote sensing of forest degradation in Southeast AsiaAiming for a regional view through 5-30 m satellite data," Global Ecology and Conservation, vol. 2, pp. 24-36, Dec. 2014, doi: 10.1016/j.gecco.2014.07.007

[39] M. Köhl, S. S. Magnussen, and M. Marchetti, Sampling Methods, Remote Sensing and GIS Multiresource Forest Inventory. Berlin Heidelberg: Springer-Verlag, 2006.

[40] R. Congalton and K. Green, Assessing the Accuracy of Remotely Sensed Data: Principles and Practices, Third Edition. 2019.

[41] A. Soim, "Warga Dayak Meratus Tak Lagi Lakukan Ladang Berpindah," Tabloid Sinar Tani, 2018. 